\title{
ANALISIS PENGENDALIAN MANAJEMEN INTERNAL TERHADAP KINERJA SISTEM INFORMASI AKUNTANSI PADA BANK UMUM PEMERINTAH DI WILAYAH BANDA ACEH
}

\author{
Faridah Iriani ${ }^{1}$, Yushita Marini ${ }^{2}$ \\ ${ }^{1)}$ Manajemen, Ekonomi, Universitas Terbuka \\ UPBJJ-UT Banda Aceh J1. Pendidikan, Banda Aceh, email : faridah-iriani@ecampus.ut.ac.id \\ 2) Akuntansi, Ekonomi, Universitas Terbuka \\ UPBJJ-UT Banda Aceh Jl. Pendidikan, Banda Aceh, email : yushita@ecampus.ut.ac.id
}

\begin{abstract}
This study aims to analyze the performance of the internal management control to the system accounting information on a government-owned bank in the city of Banda Aceh. The study was conducted in three state-owned commercial banks in the city of Banda Aceh, namely Rakyat Indonesia's Bank, Negara Indonesia's Bank and Tabungan Negara's Bank. Data was collected by means of documentation, interviews and questionnaires. After testing the quality of the data and then the data were analyzed using qualitative descriptive analysis of statistical data. The survey results revealed internal management control in state-owned commercial bank in the city of Banda Aceh was good enough, thereby increasing the efficiency and effectiveness of the acquisition of information. Accounting information system performance is affected by the internal management controls were nice, user involvement in system development, education and training on accounting information systems and also the presence of prominent representatives are actively involved in the information system.
\end{abstract}

\section{Keywords : Internal Management Control, System Accounting Information, Bank's}

\begin{abstract}
Abstrak: Penelitian ini bertujuan untuk menganalisis pengendalian manajemen internal terhadap kinerja sistem informasi akuntansi pada bank umum milik pemerintah di Kota Banda Aceh. Penelitian dilakukan pada tiga bank umum milik pemerintah di Kota Banda Aceh, yaitu Bank Rakyat Indonesia, Bank Negara Indonesia dan Bank Tabungan Negara. Teknik pengumpulan data dilakukan dengan cara dokumentasi, wawancara dan pengisian kuisoner. Setelah dilakukan uji kualitas data kemudian data dianalisis menggunakan analisis data statistik deskriptif kualitatif. Hasil penelitian diketahui pengendalian manajemen internal pada bank umum milik pemerintah di Kota Banda Aceh sudah cukup baik, sehingga meningkatkan efisiensi dan efektifitas terhadap perolehan informasi. Kinerja sistem informasi akuntansi dipengaruhi oleh pengendalian manajemen internal yang bagus, keterlibatan pemakai dalam pengembangan sistem, pendidikan dan pelatihan mengenai sistem informasi akuntansi dan juga keberadaan dewan pengarah yang terlibat aktif dalam sistem informasi.
\end{abstract}

Kata kunci : Pengendalian Manajemen Internal, Sistem Informasi Akuntansi, Bank.

Pada era global, persaingan sangat ketat di didunia usaha sehingga informasi yang cepat dan tepat sangat dibutuhkan, baik yang bersumber dari dalam perusahaan sendiri maupun diluar lingkungannya. Di dunia usaha, informasi akuntansi merupakan bagian yang terpenting dari seluruh informasi diperlukan dalam pengambilan keputusan. Perkembangan pengolahan data merupakan salah satu pengaruh dari teknologi komunikasi tersebut.

Baik buruknya kinerja dari sebuah sistem informasi akuntansi (SIA) dapat dilihat melalui kepuasan pemakai sistem informasi akuntansi dan pemakaian dari sistem informasi akuntansi itu 
JURNAL HUMANIORA

sendiri. Almilia dan Briliantien (2007), dalam penelitiannya mengemukakan bahwa ada beberapa faktor yang berpengaruh pada kinerja sistem informasi akuntansi, yaitu keterlibatan pemakai dalam pengembangan system, kemampuan teknik personal SI, ukuran organisasi, dukungan manajemen puncak, formalisasi pengembangan SI, program pelatihan dan pendidikan pemakai, keberadaan dewan pengarah SI dan lokasi departemen SI.

Begitu juga dengan perusahaan perbankan, Menurut Suyatno (2005), Perbankan merupakan inti dari sistem keuangan setiap negara. Sehingga diperlukan sistem informasi akuntansi yang baik dan berkualitas. Dalam rangka pemenuhan kebutuhan akan informasi akuntansi, perusahaan pada umumnya berusaha merancang suatu sistem informasi yang efektif dan efisien. Sistem informasi yang efektif dan efisien bisa terwujud jika didukung sarana dan prasarana yang memadai serta perangkat pelaksana yang bisa diandalkan.

Penggunaan teknologi informasi dalam kegiatan perbankan sudah sedemikian rupa luasnya, mencakup seluruh aspek aktivitas bank, baik untuk yang bersifat akuntansi, banking operation maupun kegiatan pelayanan dan nasabah. Di dunia perbankan, pelayanan merupakan hal yang sangat penting karena mereka langsung berhadapan dengan nasabah. Sistem informasi yang ada pada bank biasanya digunakan untuk memudahkan nasabah dalam melakukan transaksi, pengambilan uang, dan pengecekan saldo.

Berdasarkan dari latar belakang diatas, maka pokok masalah penelitian ini adalah bagaimanakah penerapan sistem akuntansi dalam memberikan informasi dapat meningkatkan efektivitas dan efisiensi, apa saja faktor-faktor yang mempengaruhi kinerja sistem informasi akuntansi, dan bagaimana pengendalian manajemen bank umum pemerintah di Kota Banda Aceh terhadap pengolahan transaksi dan data akuntansi?

\section{KAJIAN PUSTAKA}

\section{Pengertian Sistem}

Hall (2009) mengartikan sistem adalah kumpulan dua atau lebih komponen-komponen yang saling berkaitan, komponen tersebut berhubungan erat satu sama lain dan tidak dapat berdiri sendiri, mereka saling berinteraksi dan saling membentuk satu kesatuan sehingga tujuan atau sasaran suatu sistem dapat tercapai.

\section{Pengertian Informasi}

Bodnar dan Hopwood (2006) mendefinisikan informasi sebagai data yang dimiliki oleh perusahaan kemudian diolah sehingga menjadi informasi yang dapat digunakan sebagai bahan pertimbangan untuk pengambilan keputusan.

\section{Pengertian Sistem Informasi Akuntansi}

Baridwan (2009) menyatakan bahwa sistem informasi akuntansi adalah suatu komponen organisasi yang mengumpulkan, menggolongkan, mengolah, menganalisa, dan mengkomunikasikan informasi keuangan yang relevan untuk pengambilan keputusan.

\section{Sistem Informasi Akuntansi Berbasis}

\section{Komputer}

Bodnar dan Hopwood (2006) berpendapat bahwa sistem informasi berbasis komputer adalah

Volume 1, No. 1, April 2017 
rangkaian perangkat keras dan perangkat lunak yang dirancang untuk mengolah data menjadi informasi yang berguna. Adapun komputer dapat dikelompokkan menjadi empat komponen, yaitu: Hardware (perangkat keras), software (perangkat lunak), brainware (perangkat pelaksana) dan database.

\section{Faktor yang mempengaruhi kinerja SIA}

Khalil (1997) dalam Jen (2002) mengukur sistem informasi dengan menggunakan kepuasan pemakai dan pemakaian sistem. Soegiharto (2001) mengukur kinerja sistem informasi akuntansi dari sisi pemakai (user) dengan membagi kinerja sistem informasi akuntansi kedalam dua bagian, yaitu kepuasan pemakai sistem informasi akuntansi dan pemakaian sistem informasi akuntansi sebagai pengganti variabel kinerja sistem informasi akuntansi. Penelitian ini mengukur kinerja sistem informasi akuntansi dari dua pendekatan yaitu kepuasan pemakai sistem informasi akuntansi dan pemakaian sistem informasi akuntansi itu sendiri oleh para karyawan dalam menyelesaikan pekerjaan mereka untuk mengolah data-data keuangan menjadi informasi akuntansi. Berdasarkan penelitian terdahulu, beberapa faktor yang mempengaruhi kinerja sistem informasi akuntansi diantaranya keterlibatan pemakai dalam proses pengembangan sistem, kemampuan teknik personal sistem informasi, ukuran organisasi, dukungan manajemen puncak, formalisasi pengembangan sistem informasi, program pelatihan dan pendidikan pemakai, keberadaan dewan pengarah sistem informasi, lokasi dari departemen sistem informasi.

\section{Akuntansi Perbankan}

Perbankan merupakan suatu badan lembaga keuangan, yang melaksanakan berbagai macam jasa perantara untuk menarik uang dari dan menyalurkannya ke dalam masyarakat. Menurut IAI (2002) bank adalah usaha untuk menghimpun data dari masyarakat dalam bentuk simpanan dan menyalurkannya kepada masyarakat dalam bentuk kredit dan/atau bentuk lainnya. Proses akuntansi bank berkembang dari teknik-teknik akuntansi tradisional untuk kepentingan pencatatan, penganalisaan dan penafsiran data keuangan guna memenuhi kebutuhan pihak yang berminat terhadap informasi tersebut. Setiap bank harus memelihara catatan-catatan guna pendataan bagi kepentingan laporan tentang kondisi bank, laporan pendapatan dan biaya, serta untuk perhitungan pajak.

\section{Analisis Pengendalian Manajemen Internal}

Menurut Batinggi dan ahmad (2007), pengendalian artinya pengukuran dan perbaikan terhadap pelaksanaan kerja bawahan agar tujuan organisasi dapat terselenggara. Manajemen internal merupakan kemampuan untuk menggerakkan atau memanfaatkan sumber daya yang ada pada suatu organisasi dalam pelaksanaan pekerjaan sejak permulaan sampai berakhirnya tugas/pekerjaan itu agar tujuan organisasi dapat tercapai.

IAI (2001) mendefinisikan pengendalian intern sebagai proses yang dijalankan oleh dewan komisaris, manajemen dan personal lain untuk memberi keyakinan tentang capaian tiga tujuan berikut ini: (a) keandalan pelaporan keuangan, (b) efektivitas dan efisiensi operasi, dan (c) kepatuhan terhadap hukum dan peraturan yang berlaku. 
Pengendalian manajemen intern terdiri dari lima komponen, yaitu lingkungan pengendalian, penaksiran resiko, aktivitas pengendalian, informasi akuntansi dan pemantauan.

\section{METODE PENELITIAN}

\section{Tempat Penelitian}

Tempat penelitian ini dilakukan pada bank umum pemerintah di Kota Banda Aceh yaitu pada Bank Rakyat Indonesia, Bank Negara Indonesia dan Bank Tabungan Negara.

\section{Definisi Operasional Variabel}

Variabel bebas penelitian ini adalah pengendalian manajemen internal $(\mathrm{X})$, terdiri atas lingkungan pengendalian sistem informasi akuntansi $\left(\mathrm{X}_{1}\right)$, penaksiran resiko sistem dan siklus transaksi $\left(\mathrm{X}_{2}\right)$, aktivitas pengendalian proses akuntansi komputerisasi $\left(\mathrm{X}_{3}\right)$, pengolahan informasi dan komunikasi $\left(\mathrm{X}_{4}\right)$, dan proses pemantauan dan dukungan pemakaian sistem informasi akuntansi $\left(\mathrm{X}_{5}\right)$ menentukan kualitas kinerja pengendalian intern. Variabel terikat dalam penelitian ini adalah kinerja sistem informasi akuntansi (Y) merupakan suatu sistem informasi akuntansi yang digunakan perusahaan sebagai patokan pengendalian manajemen internal untuk sistem informasi akuntansi dan siklus-siklus transaksi yang terjadi diperusahaan perbankan. Mulai dari pengetahuan pemakai dalam penggunaan sistem informasi dan siklus transaksi $\left(\mathrm{Y}_{1}\right)$, keterlibatan frekuensi pemakaian sistem $\left(\mathrm{Y}_{2}\right)$, keterlibatan pemakai dalam pengembangan sistem informasi akuntansi $\left(\mathrm{Y}_{3}\right)$, pelatihan dan pendidikan mengenai sistem informasi akuntansi $\left(\mathrm{Y}_{4}\right)$ sampai kepuasan pemakai sistem informasi akuntansi $\left(\mathrm{Y}_{5}\right)$.

\section{Populasi dan Sampel}

Populasi penelitian ini adalah seluruh pegawai pada bank umum milik pemerintah di Kota Banda Aceh pada departement operasional, financial dan departement lainnya yang menggunakan sistem informasi akuntansi. Dari lima bank umum milik pemerintah di Kota Banda Aceh, penulis hanya mendapat izin dari tiga bank umum milik pemerintah, yaitu Bank Rakyat Indonesia, Bank Negara Indonesia dan Bank Tabungan Negara. Dengan menggunakan teknik purposive sampling, kemudian ditetapkan sebanyak 10 responden dari setiap bank, sehingga sampel pada penelitian ini adalah sebanyak 30 orang responden.

\section{Teknik Pengumpulan Data}

Untuk memperoleh data penelitian ini, penulis menggunakan cara sebagai berikut :

1. Mengumpulkan data pengendalian manajemen internal dan sistem informasi akuntansi berbasis komputer.

2. Wawancara langsung dengan departement operasional, departement financial dan departemen lainnya yang berhubungan dengan sistem informasi akuntansi dan pengendalian manajemen internalnya.

3. Pengisian kuesioner yang telah disusun oleh peneliti dan ditujukan kepada para pegawai beserta kepala bagian yang ada di bank pemerintahan setempat. Penulis telah menyediakan 30 pertanyaan untuk satu paket kuesioner yang berhubungan dengan pengendalian manajemen internal sistem 
informasi akuntansi.

\section{Metode Analisis Data}

Teknik analisis data yang digunakan adalah teknik statistik deskriptif merupakan statistik yang berfungsi untuk mendiskripsikan atau mencari gambaran terhadap obyek yang diteliti melalui data sampel atau populasi sebagaimana adanya, tanpa melakukan analisis dan membuat kesimpulan yang berlaku untuk umum (Sugiono, 2004). Hasil analisa dan evaluasi akan ditarik sebagai kesimpulan untuk memberikan gambaran dan deskripsi yang sesuai dengan yang terjadi di lapangan guna menjawab permasalahan yang muncul dalam penelitian ini. Dalam penelitian ini juga dilakukan uji kualitas data, dengan cara melakukan uji validitas dan reabilitas data.

\section{HASIL DAN PEMBAHASAN}

Responden yang telah mengisi kuesioner merupakan karyawan pemakai sistem informasi akuntansi di tiga bank umum milik pemerintah di Kota Banda Aceh. Dari 30 kuisoner yang layak digunakan untuk memperoleh data, masingmasing 10 kuisoner berasal dari Bank Rakyat Indonesia, Bank Tabungan Negara dan Bank Negara Indonesia.

\section{Deskripsi Responden}

Deskripsi responden penelitian ini adalah yang berusia antara 20 sampai 24 tahun $6,7 \%$, usia responden paling banyak pada penelitian ini adalah antara usia 25 sampai 29 tahun yaitu sebesar 15 responden atau $50 \%$ dan yang berusia 30 sampai 34 tahun sebesar 10 responden atau 33,3\%, usia 35 sampai 39 tahun sebesar 2 responden atau 6,7\% dan usia 40 sampai 45 tahun hanya 1 responden atau 3,3\%. Sementara untuk pendidikan responden pada penelitian ini adalah SMA sebesar 0 responden atau $0 \%$, Diploma sebesar 6 responden atau 20\%, Sarjana sebesar 22 responden atau $73,3 \%$ dan Pasca Sarjana sebesar 2 responden atau $6,7 \%$.

\section{Uji Kualitas Data}

Penelitian ini melakukan pengujian validitas dan reliabilitas terhadap kuesioner penelitian yang digunakan. Hasil pengujian menyatakan bahwa seluruh pernyataan dalam kuesioner dapat dikatakan valid dan reliabel. Ini berarti kuesioner layak digunakan untuk mencari data.

\section{Pengendalian Manajemen Internal}

Lingkungan pengendalian sistem informasi akuntansi adalah tindakan pemakai sistem itu sendiri dalam mengawasi komputer yang digunakan seperti menggunakan pasword untuk mengakses penyimpanan data di komputer. Berdasarkan hasil penelitian, sebesar 93,3\% responden melakukan intruksi terlebih dahulu, apabila ada pengguna lain di luar pegawai yang akan menggunakan komputer. Untuk pengendalian arsip, seluruh responden atau $100 \%$ responden melakukan pengamanan dengan menggunakan pasword dan crytography untuk mengakses arsip data di komputer. Sementara untuk bukti transaksi, sebanyak 29 responden atau sebesar 96,7\% responden dimintai bukti dari suatu transaksi yang telah diinput dalam laporan keuangan yang disimpan di komputer. Dengan demikian lingkungan pengendalian sistem informasi akuntansi pada bank umum pemerintah di Kota 
Banda Aceh sudah baik.

Variabel penaksiran resiko sistem dan siklus transaksi, membahas pemahaman pemakai sistem informasi akuntansi dalam pengembangan perancangan audit, teknik pengolahan file serta tanggung jawab pemakai sistem informasi akuntansi dalam untuk mengoreksi kekeliruan program dan data. Dari penelitian diketahui bahwa hanya sebesar 50\% responden yang memiliki pengetahuan memadai dalam pengembangan perancangan audit dan supervisi pelaksanaan sementara 50\% lainnya tidak. Sebesar 63,3\% responden memiliki pengetahuan mengenai teknik pengolahan data dan hanya $43,3 \%$ responden yang melakukan koreksi terhadap program dan kekeliruan data. Berdasarkan data dapat disimpulkan bahwa, kemampuan pengguna sistem informasi akuntansi pada bank umum milik pemerintah di Kota Banda Aceh dalam penaksiran resiko sistem dan siklus transaksi kurang memadai.

Aktivitas pengendalian proses akuntansi komputerisasi, berdasrkan data yang diperoleh responden yang mengetahui signifikannya transaksi keuangan sebesar $83,3 \%$, hanya 5 responden atau 16,7\% yang tidak mengetahui. Sementara untuk persyaratan pengamanan, backup dan penyimpanan data ke komputer seluruh responden atau 100\% melakukannya. Sebanyak 24 responden atau $80 \%$ mengaku atasannya melakukan pemisahan tugas dan melakukan pemutaran tugas diantara pegawai dan merkonsiliasi saldo yang dihasilkan oleh sistem dengan akun pengendalian dalam buku besar. Dengan hasil masing-masing indikator yang lebih dari $80 \%$ bahkan mencapai $100 \%$ maka dapat disimpulkan bahwa aktivitas pengendalian proses akuntansi pada bank umum milik pemerintah di Kota Banda Aceh secara umum sangat baik.

Pengolahan informasi dan komunikasi berhubungan dengan pengetahuan pengguna sistem mengenai komponen sistem pengolahan transaksi berbasis komputer seperti input data, processing data, storage data dan ouput informasi. Pemisahan departemen sistem informasi dengan departemen yang lain juga bagian dan komunikasi antar departemen juga bagian dari pengolahan informasi dan komunikasi.Berdasarkan data diketahui bahwa, hanya 50\% responden yang menguasai komponen sistem pengolahan transaksi berbasis komputer, sebesar $56,7 \%$ responden mengatakan departemen sistem informasi di tempat bekerja terpisah degan departemen lainnya sementara untuk komunikasi informasi antar departemen $86,7 \%$ responden menjawab sering melakukannya. Secara umum indikator pengolahan informasi sudah cukup baik dengan adanya komunikasi antar departemen, hanya saja masih rendahnya pengetahuan responden dalam menguasai komponen sistem pengolahan transaksi.

Variabel proses pemantauan dan dukungan pemakaian sistem informasi akuntansi memiliki beberapa indikator seperti periodik terhadap skedul pengolahan data yang dilakukan atasan setiap responden, ketertarikan karyawan menggunakan sistem yang ada dan melakukan update sistem informasi akuntansi komputerisasi di departemen responden bekerja. Dari hasil penelitian diketahui bahwa sebanyak 25 responden atau sebesar 83,3\% responden mengatakan atasan mereka melakukan review periodik terhadap skedul pengolahan data, sebesar 83,3\% responden mengatakan sebagian besar karyawan di departemen mereka tertarik 
untuk menggunakan sistem yang ada. Sementara 25 responden atau sebesar 83,3\% responden mengatakan sering dilakukannya update sistem informasi akuntansi komputerisasi secara berkala di departemen mereka bekerja. Berdasarkan penjabaran tersebut, proses pemantauan dan dukungan pemakaian sistem informasi akuntansi pada bank umum pemerintah di Kota Banda Aceh sudah cukup bangus dengan indikator masingmasing mencapai $83 \%$.

\section{Kinerja Sistem Informasi Akuntansi}

Pengetahuan pemakai dalam pengunaan sistem informasi dan siklus transaksi akuntansi berhubungan tentang kemampuan responden menggunakan komputer seperti microsoft office, pengetahuan mengenai komponen-komponen elektronik yang dipakai untuk menoprasikan komputer serta pengetuan khusus sistem pengolahan transaksi berbasis komputer dan teknik pengolahan data. Dari data yang diperoleh diketahui bahwa, seluruh responden atau sebesar $100 \%$ dapat mengoperasikan komputer dangan baik dan mengetahui dasar komputer secara umum. Untuk pengetahuan mengenai komponen elektronik seperti software, hardware, database sebesar 60\% respondon sudah menguasainya. Sementara untuk pengetahuan pogram khusus sistem pengolahan data, sebanyak 18 responden atau sebesar $60 \%$ sudah mengetahui dan menguasainya. Secara umum dapat disimpulkan bahwa, pengetahuan pemakai dalam penggunaan sistem informasi dan siklus transaksi akuntansi sudah bagus.

Keterlibatan dan frekuensi pemakaian sistem informasi secara umum sudah sangat bagus Volume 1, No. 1, April 2017 dimana berdasarkan data diketahui bahwa untuk lama penggunaan sistem informasi akuntansi di perusahaan, dengan pilihan satu tahun atau lebih dari satu tahun, sebesar 24 responden atau $80 \%$ menjawab telah menggunakan sistem informasi akuntansi lebih dari satu tahun, hanya enam responden atau $20 \%$ yang menggunakan sistem informasi kurang dari satu tahun. Untuk penggunaan sistem informasi, sebesar 93,3\% responden mengatakan suka atau ingin terus menggunakan sistem informasi. Sementara itu, untuk lama pengguaan komputer di perusahaan sebesar $86,7 \%$ responden menggunakan komputer lebih dari 5 jam setiap harinya, hanya 13\% responden yang menggunakan komputer kurang dari 5 jam per hari.

Berdasarkan hasil penelitian mengenai keterlibatan pemakai dalam pengembangan sistem informasi akuntansi diketahui bahwa sebesar 21 responden atau $70 \%$ responden memiliki kebijakan untuk mencegah pengkopian program dan data tanpa izin. Untuk partisipasi dan pengaruh responden dalam pengembangan sistem di perusahaan seluruh responden atau sebesar $100 \%$ mengatakan berpartisi dengan baik dalam pengembangan sistem informasi akuntansi. Sementara untuk kemampuan spesialis, hanya 50\% responden yang memiliki kemampuan spesialis yang berhubungan dengan sistem atau kemampuan umum yang berhubungan dengan organisasi, manusia dan lingkungan. Keterlibatan pemakai dalam pengembangan sistem informasi akuntansi secara umum sudah bagus terutama menyangkut partisipasi responden yang mencapai $100 \%$ dalam partisipasi pengembangan pogram. Hanya saja pegawai yang memiliki kemampuasn 
spesialis hanya $50 \%$, akan tetapi secara akumulasi indikator dari keterlibatan pemakai dalam pengembangan sistem informasi akuntansi sudah sangat bagus.

Berdasarkan hasil penelitian diketahui bahwa pelatihan dan pendidikan mengenai sistem informasi akuntansi di bank umum pemerintah di Kota Banda Aceh sudah bagus, dari tiga indikatornya pelatihan di perusahaan lain yang masih kurang didapatkan oleh pegawai bank umum milik pemerintah di Kota Banda Aceh. Hal ini sesuai dengan hasil penelitian dimana sebesar $83,3 \%$ responden mengatakan perusahaan tempat mereka bekerja memiliki pogram pelatihan dan pendidikan guna mengajarkan cara pemakaian sistem yang benar kepada staff. Untuk pelatihan dan pendidikan mengenai sistem dari perusahaan lain sebesar 53,3\% responden mengatakan tidak ada, hanya $46,7 \%$ responden yang pernah melakukan pelatihan dan pendidikan di perusahaan lain. Sebanyak 25 responden atau sebesar 83,3\% mengatakan perusahaan tempat mereka bekerja memiliki dewan pengarah dan terlibat untuk sistem informasi.

Variabel kepuasan pemakai sistem informasi akuntansi terdiri dari beberapa indikator, yaitu tanggapan responden mengenai kemampuan sistem dalam dalam memberikan informasi yang dibutuhkan, penting tidaknya sistem dalam kesuksesan kinerja serta mampu tidaknya sistem meningkatkan kepuasan kerja responden.berdasarkan penelitian diketahui dikethui bahwa sebesar 93,3\% responden yakin sistem mampu membantu dan memberikan informasi yang dibutuhkan departemen. Mengenai penting tidaknya sistem, seluruh responden atau
$100 \%$ mengatakan bahwa sistem penting dan memberikan kontribusi yang besar dalam kesuksesan kinerja departemen dan organisasi. Sementara untuk kepuasan kerja, 90\% responden mengatakan sangat puas dalam menggunakan sistem yang ada. Dari uraian di atas secara umum dapat disimpulkan bahwa kepuasan responden dalam pemakaian sistem informasi sudah sangat baik.

Berdasarkan penjabaran di atas, secara umum dapat disimpulkan bahwa penerapan dan pengendalian manajemen internal pada bank umum milik pemerintah di Kota Banda Aceh sudah cukup baik, hal ini meningkatkan efisiensi dan efektifitas terhadap perolehan informasi perusahaan bank umum milik pemerintah di Kota Banda Aceh. Pengendalian internal yang efektif dan efisien juga mengurangi segala bentuk kesalahan, penyelewengan dan kecurangan terhadap informasi akuntansi sehingga seluruh rahasia data informasi perusahaan terjaga dengan baik.

Kinerja sistem informasi akuntansi pada bank umum pemerintah di Kota Banda Aceh sudah baik, hal ini dibuktikan dengan konsistensi antara hasil penelitian dengan toeri yang dikemukakan oleh Jen (dalam Almilia dan Brilintien, 2007), menurutnya kinerja sistem informasi akuntansi diukur dari beberapa indikator, diantaranya adalah: mampu membantu departeman berfungsi dengan baik, meningkatkan kepuasan kerja, memberi informasi yang dibutuhkan, senang menggunakan sistem yang ada dan memberikan kontribusi dalam dalam pencapaian tujuan organisasi.

Mengacu pada penjelasan sebelumnya, kinerja sistem informasi akuntansi pada bank 
umum pemerintah di Kota Banda Aceh, sudah bagus berdasarkan indikator-indikator yang ada. Hal ini tentunya dipengaruhi oleh bagusnya pengendalian manajemen internal yang ada pada bank umum pemerintah di Kota Banda Aceh. Selain itu, bagusnya kinerja sistem informasi akuntansi pada bank umum pemerintah di Kota Banda Aceh juga dipengaruhi oleh keterlibatan pemakai dalam pengembangan sistem, pendidikan dan pelatihan mengenai sistem informasi akuntansi dan juga keberadaan dewan pengarah yang terlibat aktif dalam sistem informasi.

\section{KESIMPULAN}

Berdasarkan penelitian yang dilakukan dapat dibuat kesimpulan sebagai Berikut:

1. Penerapan dan pengendalian manajemen internal pada bank umum milik pemerintah di Kota Banda Aceh sudah cukup baik.

2. Kinerja sistem informasi akuntansi dipengaruhi oleh bagusnya pengendalian manajemen internal yang ada pada bank umum pemerintah di Kota Banda Aceh. Selain itu, juga dipengaruhi oleh keterlibatan pemakai dalam pengembangan sistem, pendidikan dan pelatihan mengenai sistem informasi akuntansi dan juga keberadaan dewan pengarah yang terlibat aktif dalam sistem informasi.

3. Pengendalian manajemen internal bank umum milik pemerintah di Kota Banda Aceh yang efektif dan efisien dalam pengolahan transaksi dan data akuntansi, mengurangi segala bentuk kesalahan, kecurangan dan penyelewengan terhadap informasi akuntansi sehingga seluruh rahasia data informasi perusahaan dapat terjaga dengan baik.

\section{DAFTAR PUSTAKA}

Agoes, Sukirno. (2004). Auditing (Pemeriksaan Akuntan). Edisi Ketiga. Jakarta: Fak. Ekonomi Univ. Islam.

Almilia, Luciana Spica dan Irmaya

Briliantien. (2007). Faktor-faktor yang mempengaruhi Kinerja Sistem Informasi Akuntansi pada Bank Umum Pemerintah di Wilayah Surabaya dan Sidoarjo. Publikasi Penelitian SI Seminar Nasional. STIE Perbanas, Surabaya.

Baridwan, Zaki. (2009). Sistem Informasi Akuntansi, Edisi Keenam. Yogjakarta: BPFE-Universitas Gadjah Mada

Batinggi, Achmad dan Badu Ahmad. (2007). $\begin{array}{lll}\text { Manajemen } & \text { Pelayanan Umum. } \\ \text { Cetakan } & \text { Kedelapan. } & \text { Jakarta: }\end{array}$ Universitas Terbuka.

Bodnar, George H, dan William S.Hopwood. (2006). Sistem Informasi Akuntansi, Edisi Kesembilan. Yogjakarta: Andi.

Hall, James A. (2001). Sistem Informasi Akuntansi. Buku 1. Edisi Pertama. Jakarta: Salemba Empat.

IAI. (2001). Standar Profesional Akuntan Publik. Jakarta: Selemba Empat.

IAI. (2002). Standar Akuntansi Keuangan. Jakarta: Salemba Empat.

Jen, Tjhai Fung. (2002). Faktor-Faktor Yang Mempengaruhi Kinerja Sistem Informasi Akuntansi. Jakarta: Jurnal Bisnis dan Akuntansi, IV(2).

Kuswandi, Daniel S. dkk. (2000). Akuntansi 
Perbankan (Akuntansi Transaksi Valuta Asing). Jilid Satu. Edisi Kelima. Jakarta: Institut Bankir Indonesia (IBI).

Mahmudi, Ali. (2005). Accurate-Sistem Informasi Akuntansi Perusahaan. Jakarta: Grasindo.

Marini, Yushita. (2006). Penerapan Sistem Informasi Akuntansi Berbasis Komputer pada PT. Bank Sumut. Publikasi: Perpustakaan Universitas Negeri Medan (untuk kalangan sendiri).

Mukhtar, Ali Masjono. (1999). Audit Sistem Informasi. Cetakan Pertama. Jakarta: PT. RINEKA CIPTA.

Mulyadi. (2002). Auditing. Buku 1. Edisi Keenam. Jakarta: Salemba Empat.
Pandia, Hendri. (2004). Teknologi Informasi dan Komunikasi. Jilid 2 Untuk SMP Kelas VIII. Jakarta: Erlangga.

Santoso, Singgih, dkk. (2004). Riset Pemasaran (Konsep dan Aplikasi dengan SPSS). Jakarta: Elex Media Komputindo.

Soegiharto. (2001). Influence Factors Affecting The Performance of Accounting Information System. Gajah Mada International Journal of Business, III (2).

Sugiono, Dr. (2004). Statistika Untuk Penelitian. Bandung: CV. ALFABETA. Suyatno, Dr. Thomas, dkk. (2005). Kelembagaan Perbankan. Edisi Ketiga. Cetakan Ketiga Belas. Jakarta: Gramedia Pustaka Utan. 